\title{
Article \\ Activation of Blast Furnace Slag with CFB Fly Ash as a Supplementary Binder Material: Hydration Products and Effects of Sulfate Attack
}

\author{
Guan-Yu Chen and Wei-Hsing Huang * (D) \\ Department of Civil Engineering, National Central University, Zhongli District, Taoyuan City 32001, Taiwan; \\ fish22740@gmail.com \\ * Correspondence: t321655@ncu.edu.tw; Tel.: +886-3-422-7151 (ext. 34136)
}

check for

updates

Citation: Chen, G.-Y.; Huang, W.-H. Activation of Blast Furnace Slag with CFB Fly Ash as a Supplementary Binder Material: Hydration Products and Effects of Sulfate Attack. Crystals 2022, 12, 41. https://doi.org/ $10.3390 /$ cryst 12010041

Academic Editors: Yi Bao, Salman Siddique, Wei-Ting Lin and Trilok Gupta

Received: 6 December 2021

Accepted: 24 December 2021

Published: 28 December 2021

Publisher's Note: MDPI stays neutral with regard to jurisdictional claims in published maps and institutional affiliations.

Copyright: (c) 2021 by the authors. Licensee MDPI, Basel, Switzerland. This article is an open access article distributed under the terms and conditions of the Creative Commons Attribution (CC BY) license (https:/ / creativecommons.org/licenses/by/ $4.0 /)$.

\begin{abstract}
Circulating Fluidized Bed (CFB) combustion is a clean technology for burning, with advantages of adapting to a large variety of fuel, high combustion efficiency, lower NOx emissions, and stable operation. The residue collected from the ash-hoppers of the electrostatic precipitator of the CFB boiler is called CFB fly ash. This paper presents the hydration development on the application of CFB fly ash to activating blast furnace slag (BFS) as a supplementary binder material (SBM) for replacement of Portland cement in making concrete. Investigation of the hydration products of cement pastes prepared with combinations of BFS and CFB fly ash were conducted by means of $\mathrm{X}$-ray diffraction, thermal gravimetric analysis, and scanning electronic microscope. Test results show that the main hydration products of the CFB fly ash-BFS blended pastes were found to be hydrated calcium silicate (C-S-H), ettringite, gypsum, and some portlandite. Considering that CFB fly ash produced from the combustion of high-sulfur coke has high $\mathrm{SO}_{3}$ contents, the volume stability of mortar made from CFB fly ash-activated BFS was subjected to tests in accordance with ASTM C1012 and ASTM C1038 for evaluating the internal and external sulfate attack, respectively. The results indicate that, due to the high sulfur $\left(\mathrm{SO}_{3}\right)$ content of $\mathrm{CFB}$ fly ash, the expansion caused by internal sulfate attack (ISA) increased with increasing proportion of CFB fly ash in the mixture. In contrast, no significant expansion was observed in the external sulfate attack (ESA) test, regardless of the proportion of CFB fly ash in the mixture. In order for the CFB fly ash to serve as a supplementary binder material and to maintain adequate volume stability, the amount of CFB fly ash used for the activation of BFS is recommended to be no more than $20 \%$ of the SBM.
\end{abstract}

Keywords: circulating fluidized bed fly ash; supplementary binder materials; internal sulfate attack; delayed ettringite formation

\section{Introduction}

Circulating fluidized bed boiler combustion is a clean technology for coal burning, which has the advantages of adapting to a large variety of fuel, high combustion efficiency, lower SOx and NOx emissions, and stable operation over a large range of load regulation. In this study, the circulating fluidized bed (CFB) boiler is a means of energy-generating process by burning petroleum coke only. The high-sulfur petroleum coke is a by-product of high-sulfur oil refining industry, with a sulfur content of approximately $7 \%$. In order to avoid blazed petroleum coke with high sulfur content from emitting overdosed sulfur dioxide $\left(\mathrm{SO}_{2}\right)$, limestone $\left(\mathrm{CaCO}_{3}\right)$ is introduced in the boiler for desulfuration. As a result, the ash collected from CFB boiler has a rich content of anhydrite.

Poon et al. [1] reported that, in the cement-fly ash binding system, calcium sulfate anhydrite can act as activating material, and a large quantity of ettringite (AFt) can be formed during the early stage of hydration in the anhydrite-activated cement-fly ash pastes. Iribarne et al. [2] and Berry et al. [3] indicated that CFB ash, rather than being particularly active in themselves, provided the components (lime, anhydrite) appropriate to induce 
sulpho-pozzolanic activity in fly ash or other pozzolans. CFB ash contains a large amount of $\mathrm{CaO}$ and forms calcium hydroxide in the presence of water. In turn, this can be used for activating the pozzolanic reaction of blast furnace slag (BFS) to generate C-S-H colloid and C-A-H columnar crystals, which improve the final strength after hydration [4]. For an admixture used in cement and concrete, the $\mathrm{SO}_{3}$ content should be kept within limits to provide resistance against severe expansion and cracking of hardened cement mixtures. In this study, the CFB fly ash is different from traditional coal-fired fly ashes having good pozzolanic and hydraulic properties $[4,5]$. The CFB fly ash is generated by firing high-sulfur petroleum coke. The ash is rich in anhydrite and free lime, while it has relatively low $\mathrm{SiO}_{2}$ and $\mathrm{Al}_{2} \mathrm{O}_{3}$ contents as well as large specific surface area [6-9].

Sung et al. [10] mixed circulating fluidized bed boiler co-firing fly ash (CFFA) with ground granulated blast-furnace slag (BFS) to prepare mortar specimens and then subjected to compressive strength and volume stability testing. It was found that when the CFFA content exceeded $40 \%$, apparent volume expansion and unstable compressive strength performance were observed. SEM and XRD analysis revealed that the volumetric expansion of the composite cement mortar might have been induced by the formation of C-A-S-H and $\mathrm{CaSO}_{4} \cdot\left(\mathrm{H}_{2} \mathrm{O}\right)_{8}$ in the presence of excessive sulfur trioxide in the mixture.

Therefore, it is important to understand the effect of using CFB fly ash as cement-BFS supplementary binder material on the volume stability of the mixture. In a previous study, Chen and Huang [11] found that the use of different combinations of CFB fly ash and BFS as supplementary binder material produced mortars with compressive strength comparable to that of ordinary Portland cement (OPC) under conditions of highly reduced cement usage of only $20 \%$. the BFS was recommended to be between $18-22 \%$ of the SBM at a reduced cement usage of $20 \%$.

In this study, CFB fly ash-BFS blended mortar with $20 \%$ cement was selected for compressive strength testing, with reference to previous study [11], to investigate the strength development of CFB fly ash, using different batches of sampled at the same CFB-BFS blending ratio as a basis for assessing the quality stability of the supplementary binder material. In addition, the hydration products of cement paste made with CFB fly ash-BFS as supplementary binder material were investigated at different curing ages (one, three, and seven days) by thermal gravimetry (TG), X-ray diffraction (XRD), and scanning electron microscope (SEM) observation. In addition, volume stability tests were conducted on mortar bars mixed with different weight ratios of CFB fly ash to BFS to investigate the expansion behavior of various mixtures under internal and external sulfate attacks. And the changes of the hydration products under sulfate attack were further observed by scanning electron microscope.

\section{Materials}

The cementitious binding materials used in this study include Portland cement, blast furnace slag, and CFB fly ash. The chemical composition of the cementitious binders is summarized in Table 1.

- Portland cement (OPC):

Conforming to ASTM C150 standard specification of Portland cement Type I, with a specific gravity of 3.15 .

- $\quad$ Blast furnace slag (BFS):

The ground granulated blast furnace slag (BSF) has a blaine specific surface area greater than $400 \mathrm{~m}^{2} / \mathrm{kg}$, with a specific gravity of 2.90 . BFS is a pozzolanic admixture commonly used in cementitious materials. In this study, it was mixed with CFB fly ash and used as a supplementary binding material in replacement of cement.

- CFB fly ash:

The CFB fly ash is a powdery material collected by the CFB boiler firing high-sulfur petroleum coke. In this study, a total of 16 batches of CFB fly ash were sampled and tested 
for physical properties. The specific gravity of CFB fly ash was in the range of 2.43 to 2.91 , with an average of 2.64. The blaine fineness was found to be between 237 and $396 \mathrm{~m}^{2} / \mathrm{kg}$, with an average of $277 \mathrm{~m}^{2} / \mathrm{kg}$.

The chemical compositions given in Table 1 indicate that CFB fly ash contains high amounts of calcium oxide $(\mathrm{CaO})$ and sulfur trioxide $\left(\mathrm{SO}_{3}\right)$. Figure 1 presents the XRD pattern of CFB fly ash. It shows the distinct presence of anhydrite $\left(\mathrm{CaSO}_{4}\right)$, lime $(\mathrm{CaO})$, and calcium hydroxide $\left(\mathrm{Ca}(\mathrm{OH})_{2}\right)$.

Table 1. Chemical composition of binders (wt $\%$ ).

\begin{tabular}{cccc}
\hline & & \multicolumn{2}{c}{ Binders } \\
\cline { 2 - 4 } Composition & Portland Cement & \multicolumn{2}{c}{ Supplementary Binder Materials } \\
\cline { 2 - 4 } & & BFS & CFB \\
\hline $\mathrm{SiO}_{2}$ & 20.42 & 33.97 & 2.96 \\
$\mathrm{Al}_{2} \mathrm{O}_{3}$ & 4.95 & 14.69 & 0.86 \\
$\mathrm{Fe}_{2} \mathrm{O}_{3}$ & 3.09 & 0.34 & 0.52 \\
$\mathrm{CaO}$ & 61.69 & 42.01 & 54.48 \\
$\mathrm{MgO}_{\mathrm{SO}}$ & 3.29 & 6.26 & 1.36 \\
$\mathrm{~K}_{2} \mathrm{O}$ & 2.40 & 0.41 & 25.17 \\
$\mathrm{Na}_{2} \mathrm{O}$ & - & 0.27 & 0.36 \\
$\mathrm{Free}_{-\mathrm{CaO}}$ & - & 0.15 & 0.05 \\
\end{tabular}

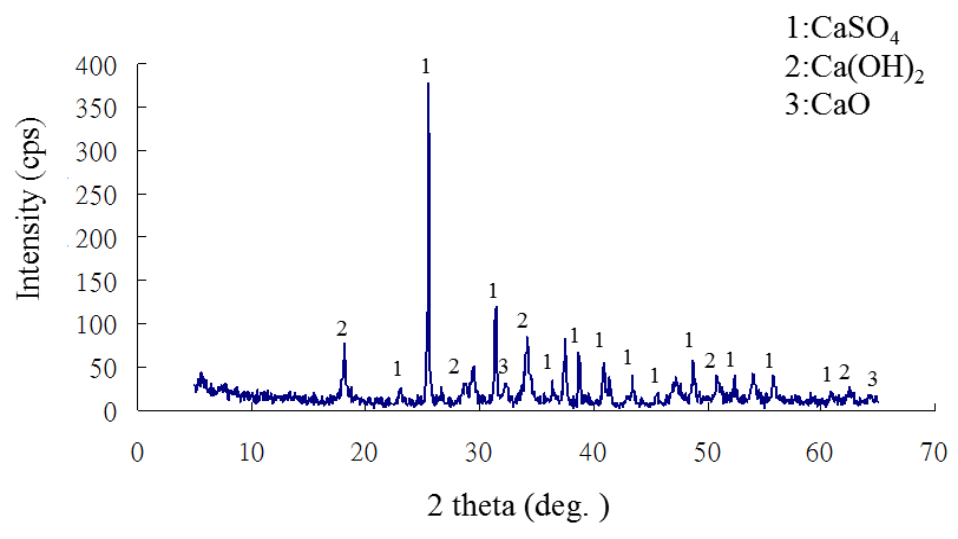

Figure 1. XRD pattern of CFB fly ash.

\section{Experimental Methods}

In this study, the mixing ratios of Portland cement, CFB fly ash, and BFS were selected based on the results of previous studies [11], and the experiment can be divided into two parts:

1. The same cement-CFB fly ash-BFS mixed binder ratio was used to make mortar specimens to test for compressive strength and to evaluate the quality stability of CFB fly ash material from different sampled batches.

2. Different proportions of CFB fly ash were mixed with BFS and used as supplementary binder material to replace Portland cement in making mortar bars for determination of volume change upon sulfate attack. 


\subsection{Compressive Strength}

A mixture of $16 \%$ CFB fly ash, $64 \%$ BFS, and $20 \%$ cement was selected, based on the results from a previous study [11], as binder in making mortar specimens for compressive strength testing. A total of 16 batches of CFB ash was sampled on a weekly basis during a period of 4 months. This was intended to assess the quality stability of the CFB fly ash. The compressive strength of $50 \times 50 \times 50$-mm mortar specimens were determined at 3, 7, 28 , and 56 days using a universal testing machine according to ASTM C109. The mortar used with a water to binder ratio (W/B) of 0.476 , and 1 part binder and 2.75 parts of sand proportioned by mass. The specimens were cast and kept in molds for $24 \mathrm{~h}$, and then, they were demolded and moved into a curing room at relative humidity of $100 \%$ and $23^{\circ} \mathrm{C}$ until testing.

\subsection{Hydration Products Investigation}

In order to investigate the hydration products formed on the use of CFB fly ash to activate BFS as supplementary binder materials (SBM) for replacement of Portland cement, a combination of $20 \%$ cement, $64 \%$ BFS, and $16 \%$ CFB fly ash was selected to make mixtures for experimental studies. The hydration products were analyzed by thermal gravimetry (TG), X-ray diffraction (XRD), and scanning electron microscope (SEM) on the blended paste specimens at different ages (1,3, and 7 days).

\subsubsection{Thermal Gravimetric (TG) Analysis}

The test samples were obtained from the inner core of paste cubes. The amount of material to be subjected to TG analysis was crushed and ground until a grain size of $45 \mu \mathrm{m}$ is obtained. The apparatus used in the thermogravimetric studies was a Perkin Elmer TGA-7. The thermal gravimetric test was conducted to quantitatively estimate the calcium hydroxide $(\mathrm{CH})$ and other hydration products at a heating rate of $20^{\circ} \mathrm{C} / \mathrm{min}$ from $30^{\circ} \mathrm{C}$ to $900^{\circ} \mathrm{C}$ under nitrogen atmosphere.

\subsubsection{X-ray Diffraction (XRD) Analysis}

Randomly oriented powder specimens (passing No. 325 sieve) for XRD analysis were prepared by grinding small portions of the dried pastes. After that, the sample was dried at $60^{\circ} \mathrm{C}$ for $6 \mathrm{~h}$. The dried sample was prepared for analysis by an X-ray diffractometer with $\mathrm{Cu} \mathrm{K} \alpha$ radiation. Step scan was performed over the range of $5^{\circ}$ to $60^{\circ}(2 \theta)$ with stepping interval of $0.02^{\circ}$ and a scanning rate of $5.00^{\circ} / \mathrm{min}$.

XRD analysis was performed on (a) CFB fly ash paste and (b) cement-CFB fly ash-BFS blended paste at $1 \mathrm{~h}$ to 7 days after hydration.

\subsubsection{Scanning Electron Microscope (SEM)}

The sample for the scanning electron microscope was obtained from hardened blended paste specimen, immersed in acetone for $24 \mathrm{~h}$ after crushing process and then dried at $60^{\circ} \mathrm{C}$ for $6 \mathrm{~h}$. SEM analyses were performed by using a JSM-7000F scanning electron microscope with an energy dispersive Spectroscopy (EDS).

\subsection{Volume Stability Test (Effects of Sulfate Attack)}

The detailed proportions of binder consisting of CFB fly ash, BFS, and cement used in preparing mortars for testing are given in Table 2. All blended mortar samples had a water / binder (W/B) ratio of 0.485 and were designed and prepared according to ASTM C1012 [12] and ASTM C1038 [13], respectively. Three $25 \times 25 \times 280$-mm test specimens for each mixture were prepared. The mortar used consists of 1 part binder and 2.75 parts of sand proportioned by mass. 
Table 2. Proportions of CFB fly ash-BFS blended mortar.

\begin{tabular}{cccc}
\hline \multirow{2}{*}{ Portland Cement } & \multicolumn{2}{c}{ Supplementary Binder Materials (SBM) } & \multirow{2}{*}{ Ratio of CFB Fly Ash/SBM } \\
\cline { 2 - 3 } & BFS & CFB Fly Ash & $0 \%$ \\
\hline & $80 \%$ & $0 \%$ & $10 \%$ \\
$20 \%$ & $72 \%$ & $12 \%$ & $15 \%$ \\
& $68 \%$ & $16 \%$ & $20 \%$ \\
& $64 \%$ & $20 \%$ & $25 \%$ \\
\hline
\end{tabular}

\section{Results and Discussion}

\subsection{Compressive Strength Development}

Figure 2 shows the compressive strength development of mortars made with a blend of $20 \%$ cement, $64 \%$ BFS, and $16 \%$ CFB fly ash as binder at the curing ages of 3, 7, 28 and 56 days, where the blend was prepared using CFB fly ash sampled from the power plant at 16 different times covering a period of four months. It can be observed that the compressive strength of mortars made using different batches of CFB fly ash shows similar trend in the development with age.

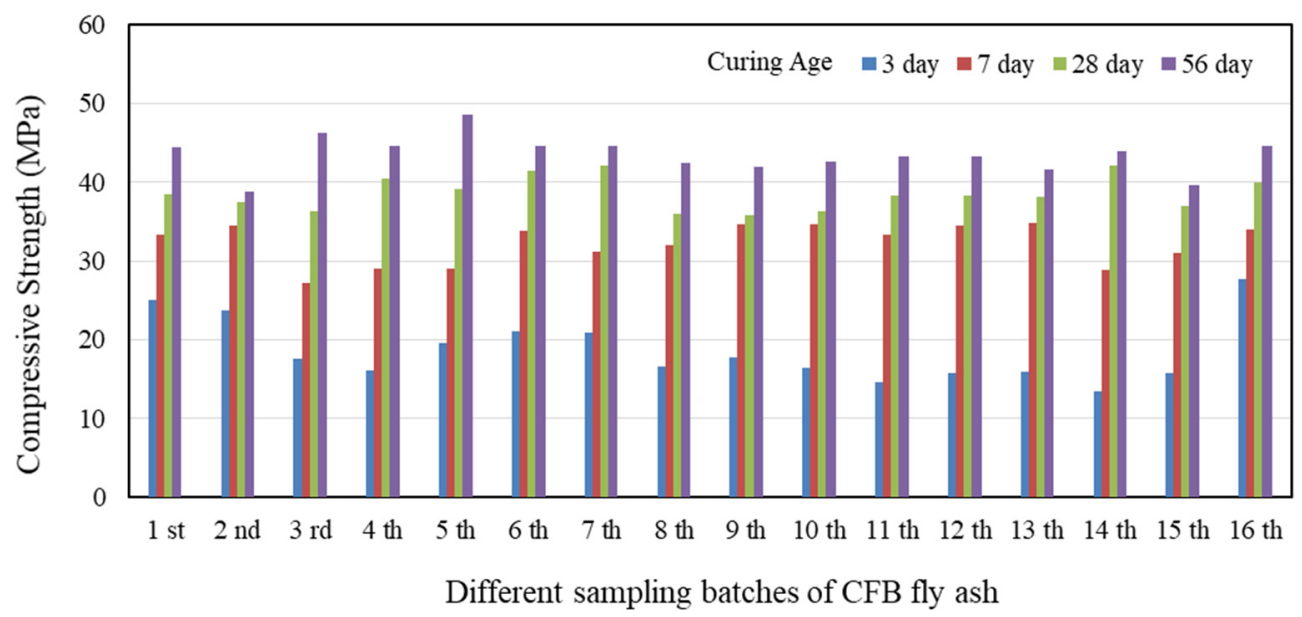

Figure 2. The compressive strength development of mortar specimens made using 16 different batches of CFB fly ash.

A statistical analysis of the compressive strength data is shown in Table 3. The variation in compressive strength is relatively high in the early ages (three and seven days), and as the age increases, the variation decreases significantly. Overall, the statistical results show that mortars prepared using CFB fly ash-activated BFS and low cement content (20\%) not only has steady strength development at all curing ages but also exhibits good-quality stability for different batches of CFB fly ash, as manifested by the standard deviation (SD) and coefficient of variation of the compressive strength.

Table 3. Statistical analysis on the compressive strength of CFB fly ash-BFS-cement mixed mortar (16 samplings).

\begin{tabular}{ccccc}
\hline $\begin{array}{c}\text { Curing Age } \\
\text { (Days) }\end{array}$ & $\begin{array}{c}\text { Strength Range } \\
\text { (MPa) }\end{array}$ & $\begin{array}{c}\text { Average } \\
\text { (MPa) }\end{array}$ & $\begin{array}{c}\text { SD }(\sigma) \\
\text { (MPa) }\end{array}$ & $\begin{array}{c}\text { Coeff. of } \\
\text { Variation (\%) }\end{array}$ \\
\hline 3 & $13.4-27.8$ & 19.0 & 3.1 & 16 \\
7 & $27.2-34.9$ & 31.1 & 2.7 & 9 \\
28 & $35.9-44.1$ & 40.1 & 2.4 & 6 \\
56 & $38.9-48.5$ & 44.6 & 2.8 & 6 \\
\hline
\end{tabular}




\subsection{Hydration Products}

\subsubsection{Thermal Gravimetric (TG) Analysis}

The thermal gravimetric analysis (TGA) was conducted on a paste prepared by $16 \%$ CFB fly ash, 64\% BFS, and 20\% cement, and the corresponding weight loss results are shown in Figure 3 and Table 4. Figure 3 shows that the first weight loss, which is observed between $80{ }^{\circ} \mathrm{C}$ to $425^{\circ} \mathrm{C}$, accounts for about $4.26-7.46 \%$ of the sample at different curing ages (1-7 days). The weight loss in the temperature range of $80{ }^{\circ} \mathrm{C}$ to $200{ }^{\circ} \mathrm{C}$ results from the dehydration reactions of gypsum and ettringite. The bonded water in the C-S-H phases is dehydrated upon achieving temperatures of about $425^{\circ} \mathrm{C}$, which also includes the dehydration of the C-A-S-H and C-A-H phases formed by cement hydration and pozzolanic reaction [14]. The formation of C-S-H gel is a main phase of the cement base composition after hydration. Because of its complex structure, the dehydration of C-S-H is a multi-step reaction.

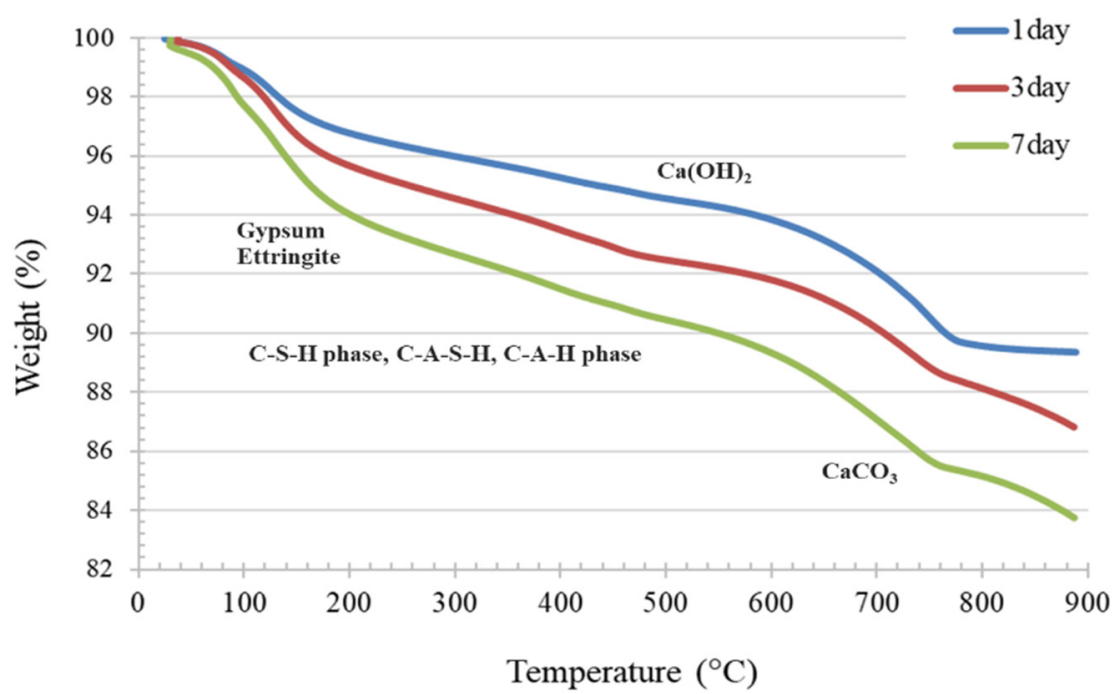

Figure 3. TGA heating curve of CFB fly ash-BFS-cement blended paste.

Table 4. Calculated weight loss of paste at different ages.

\begin{tabular}{lcccc}
\hline \multicolumn{1}{c}{ Composition } & $\begin{array}{c}\text { Temperature } \\
\text { Range }\left({ }^{\circ} \mathbf{C}\right)\end{array}$ & 1 Day & 3 Days & 7 Days \\
\cline { 3 - 5 } & & & & \\
\hline $\begin{array}{l}\text { Gypsum, Ettringite } \\
\text { C-S-H phase, }\end{array}$ & $80-425$ & 4.26 & 6.04 & 7.46 \\
C-A-S-H, C-A-H phase & & & & \\
$\mathrm{Ca}(\mathrm{OH})_{2}$ & $450-550$ & 0.63 & 0.71 & 0.96 \\
$\mathrm{CaCO}_{3}$ & $600-750$ & 3.31 & 2.96 & 3.64 \\
\hline
\end{tabular}

The second part of the weight loss takes place between $450{ }^{\circ} \mathrm{C}$ to $550{ }^{\circ} \mathrm{C}$, corresponding to the loss of water from portlandite $(\mathrm{CH})$ decomposition [14], represents about $0.63-0.96 \%$ weight loss of the sample. The third part of the weight loss occurs between $600{ }^{\circ} \mathrm{C}$ to $750{ }^{\circ} \mathrm{C}$. This loss is attributed to the dehydration of constitution water and decomposition of carbonate $\left(\mathrm{CaCO}_{3}\right)$.

\subsubsection{XRD Analysis}

The XRD patterns of hydrated CFB fly ash are shown in Figure 4a. It can be seen that the main hydration products of hydrated CFB fly ash at 1-7 days are gypsum and some portlandite $(\mathrm{CH})$. The results show that the diffraction peaks of lime $(\mathrm{CaO})$ cannot be found after hydration. The reason is that lime formed at about $800-900{ }^{\circ} \mathrm{C}$ is highly reactive and hydrates to form $\mathrm{Ca}(\mathrm{OH})_{2}$ in several hours. Anhydrite $\left(\mathrm{CaSO}_{4}\right)$ diffraction peaks can be 
found at $24 \mathrm{~h}$ of hydration and become very feeble after seven days of hydration. Gypsum $\left(\mathrm{CaSO}_{4} \cdot 2 \mathrm{H}_{2} \mathrm{O}\right)$ diffraction peaks grow slowly during the first three days of hydration and become very strong after seven days of hydration. These findings prove that the hydration of anhydrite in CFB fly ash is very slow and occurs mainly in 3-7 days. However, no ettringite (AFt) was detected in hydrated CFB fly ash sample.
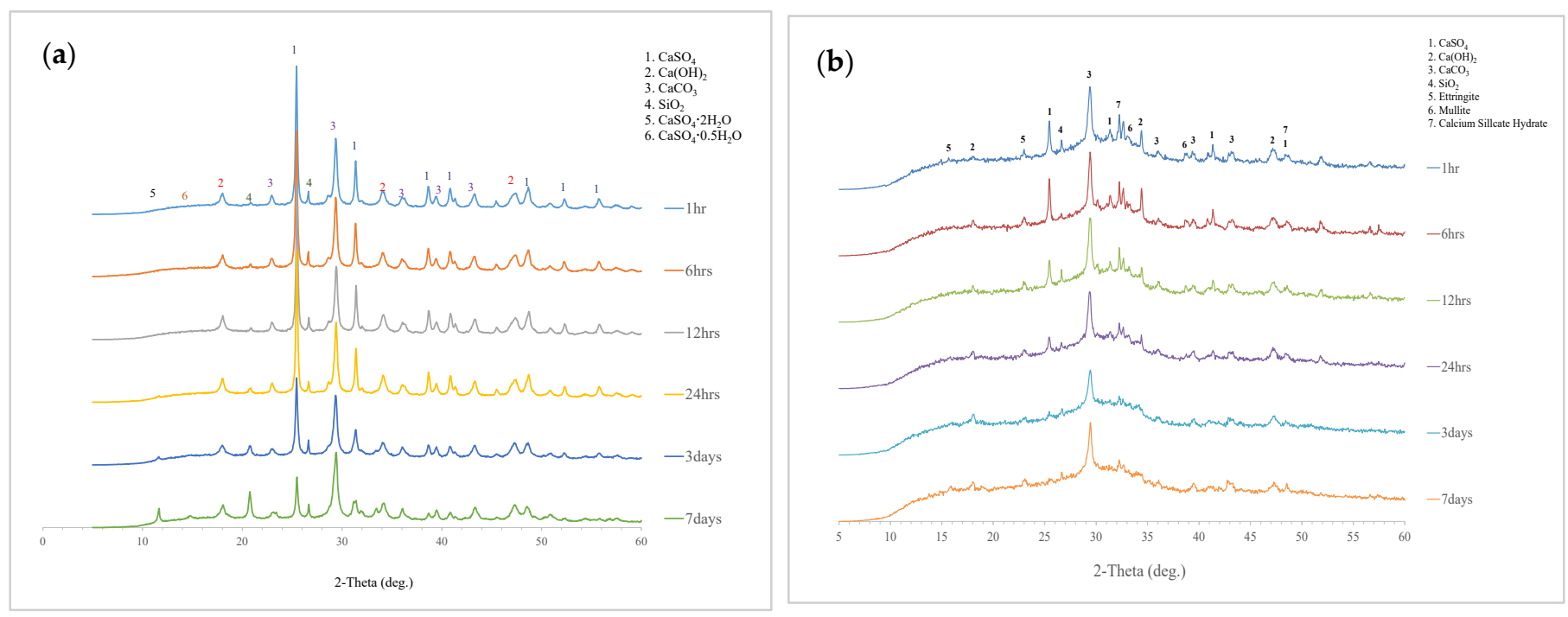

Figure 4. XRD pattern of Hydrated (a) CFB fly ash and (b) cement-CFB fly ash-BFS blended pastes from $1 \mathrm{~h}$ to $7 \mathrm{~d}$ of curing age.

The results in Figure $4 \mathrm{~b}$ show that main hydration products of $20 \%$ cement, $16 \%$ CFB fly ash, and $64 \%$ BFS blended paste at 1-7 days are anhydrite, portlandite, ettringite, and calcium silicate hydrate. The diffraction peaks of anhydrite and portlandite can be found at one day of hydration and become very feeble after seven days. The other detectable phases are residual anhydrous silicates and aluminates and calcium carbonate.

The C-S-H is produced mainly by means of the reaction between $\mathrm{Ca}(\mathrm{OH})_{2}$ and active $\mathrm{SiO}_{2}$ in the CFB fly ash and BFS. Ettringite appears after $1 \mathrm{~h}$ of hydration and gradually increases due to the reaction of $\mathrm{Ca}(\mathrm{OH})_{2}$, anhydrite, and active alumina $\left(\mathrm{Al}_{2} \mathrm{O}_{3}\right)$ dissolved from CFB fly ash and BFS. The reaction is as follows:

$$
3 \mathrm{Ca}(\mathrm{OH})_{2} \cdot \mathrm{Al}_{2} \mathrm{O}_{3}+23 \mathrm{H}_{2} \mathrm{O}+3 \mathrm{CaSO}_{4} \cdot 2 \mathrm{H}_{2} \mathrm{O} \rightarrow 3 \mathrm{CaO} \cdot \mathrm{AI}_{2} \mathrm{O}_{3} \cdot 3 \mathrm{CaSO}_{4} \cdot 32 \mathrm{H}_{2} \mathrm{O} \text { (Ettringite) }
$$

\subsubsection{Scanning Electron Microscope (SEM)}

The SEM micrographs of the hydrated CFB fly ash-BFS paste sample at seven days are shown in Figure 5. It is known that cement in the mixture easily hydrates to form C-S-H gel and $\mathrm{Ca}(\mathrm{OH})_{2}$ in the presence of water. Then the pozzolanic reaction between the reactive silicon-aluminum components in CFB fly ash-BFS and the hydration product $\mathrm{Ca}(\mathrm{OH})_{2}$ occurs to produce more C-S-H gel and hydrated calcium aluminate. The latter then reacts with $\mathrm{CaSO}_{4}$ to form AFt. 


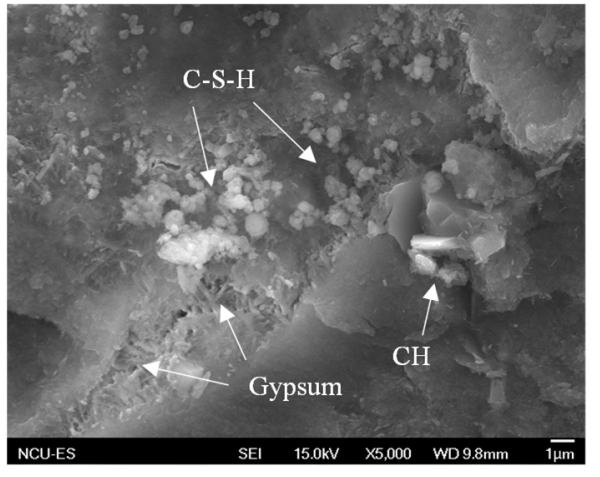

(a)

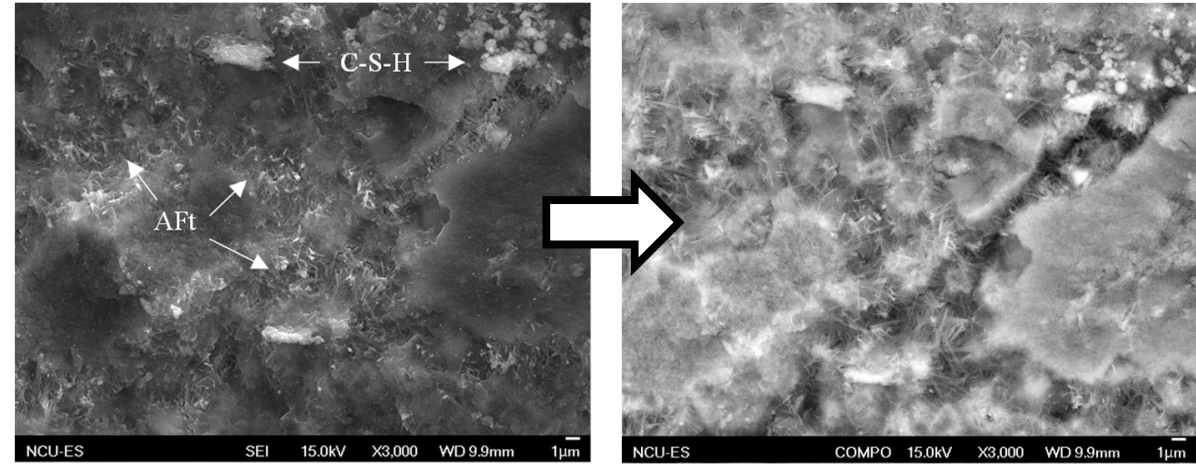

(b)

Figure 5. SEM micrograph of hydration products. (a) SEI mode; (b) BEI mode.

Figure 5a presents micrographs in SEI mode that shows many ettringite (AFt) crystals grow mixed with C-S-H gel. They are about $1-2 \mu \mathrm{m}$ in length and $0.1-0.2 \mu \mathrm{m}$ in width. Some gypsum and $\mathrm{CH}$ can also be found in the specimen. Figure $5 \mathrm{~b}$ presents the images observed in BEI mode along with the corresponding SEI imaging, which show a great deal of C-S-H gel and ettringite growth with some unhydrated silicates and aluminates.

\subsection{Volume Stability Test}

\subsubsection{External Sulfate Attack (ASTM C1012)}

Sulfate attack is potentially one of the most damaging degradation mechanisms in the study of cement-based mixtures properties. It can lead to the expansion, cracking, strength loss, and disintegration of the concrete. External sulfate attack (ESA) is generally attributed to the reaction of sulfate ions with calcium hydroxide and calcium aluminate hydrate to compose gypsum and ettringite. Expansion under sulfate attack is commonly related to the volume increase associated with ettringite occupying the space that is vacated by reacting monosulfate [15]. The secondary formation of ettringite leads to an increase in solid volume, resulting in expansion, cracking, and mass loss, particularly when the pore space is restricted. Mehta [16] also pointed out that the formation of gypsum was one of the principal causes of the expansion in sulfate environment, leading to softening and loss of mass and strength.

The sulfate resistance of the samples in this study was evaluated by ASTM C1012 metod. In this test, mortar specimens were immersed in 5\% (50 g/L) sodium sulfate solution at $23^{\circ} \mathrm{C}$, where expansion was regularly measured at certain time intervals. The expansion (failure) limit stipulated by ASTM C1012 is 0.10\%. Figure 6 shows that mortar bars made with various combinations of CFB fly ash and BFS performed very well in the sulfate solution. At an age of 270 days, it was observed that these CFB-BFS mortar bars were still performing well, and the expansion was limited to be less than $0.03 \%$. In Figure 6, the only expansion curve exceeding the $0.10 \%$ criterium was OPC mortar $(100 \%$ Portland cement) after 150 days in sodium sulfate solution. These results indicate that the mortars made with CFB fly ash and BFS exhibit much-improved resistance to external sulfate attack in comparison to OPC mortar. 


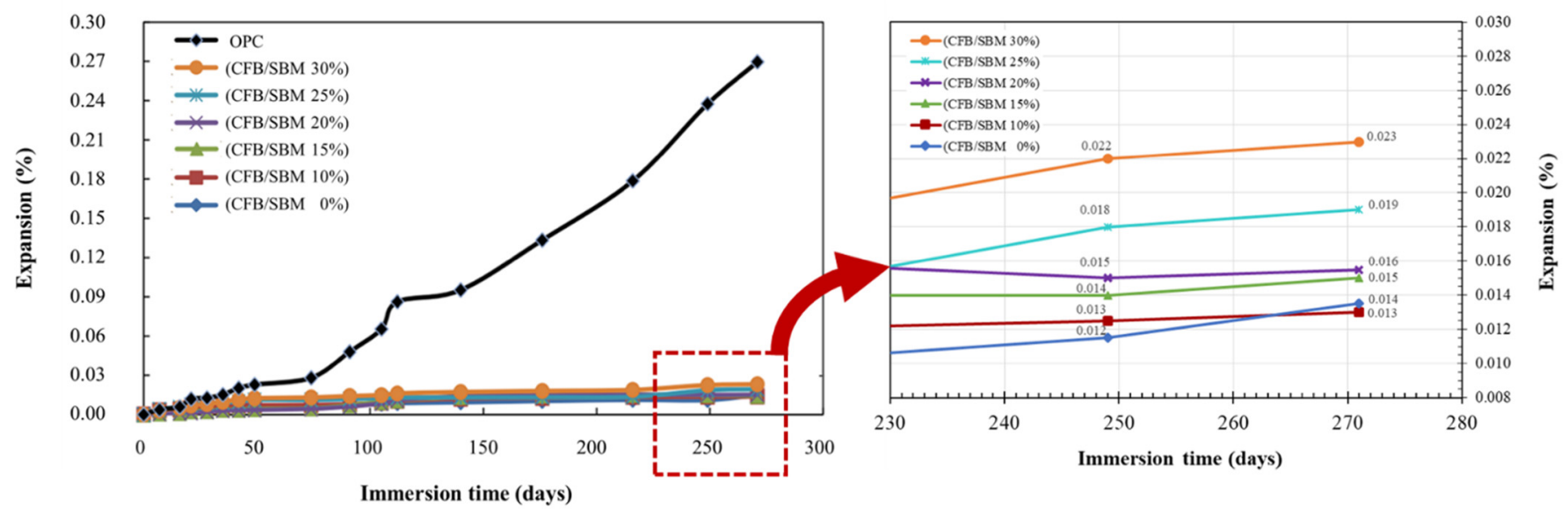

Figure 6. Expansion of mixture mortars with different CFB fly ash/SBM ratios under external sulfate attack.

The microstructure of the blended paste sample consisting of $20 \%$ cement, $64 \% \mathrm{BFS}$, and $16 \%$ CFB subjected to immersion in 5\% sodium sulfate solution for 180 days was observed by SEM. The morphology of the hydration products of the CFB-BFS blended paste under the external sulfate attack is shown in Figure 7. Figure 7a,b shows that the outer side of blended paste specimen in contact with sulfate solution has a large quantity of massive $\mathrm{Ca}(\mathrm{OH})_{2}$, short column (gypsum), and clustered (aluminosilicate) crystal depositions, as observed by SEM. In Figure 7c,d, micrograph of the inner side of the blended paste is presented. There are a significant quantity of approximately 1-2 $\mu \mathrm{m}$ length of needle-like ettringite $(\mathrm{AFt}), \mathrm{Ca}(\mathrm{OH})_{2}, \mathrm{C}-\mathrm{S}-\mathrm{H}$ gel, and amorphous hydration products formed in cracks or voids inside.

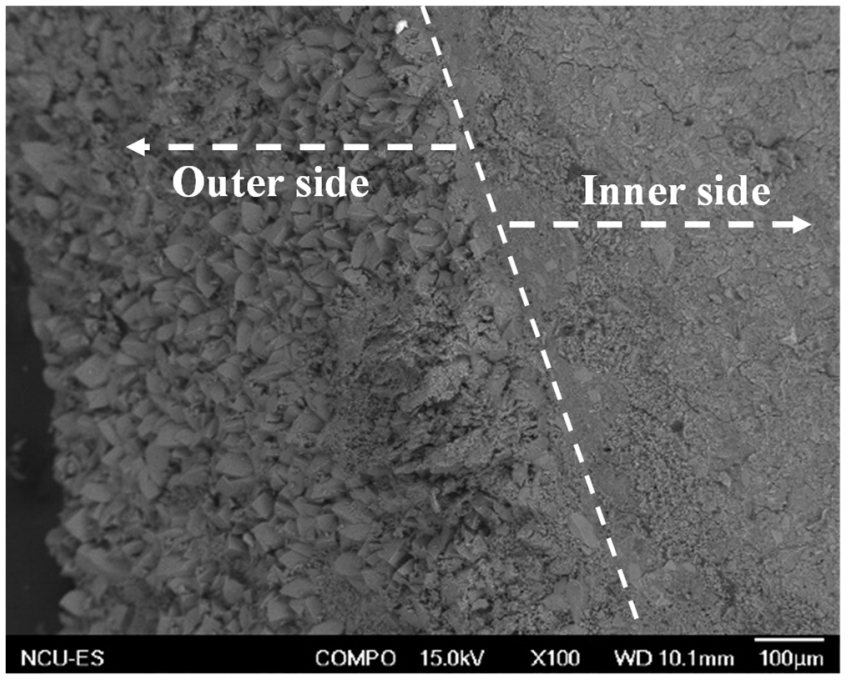

(a)

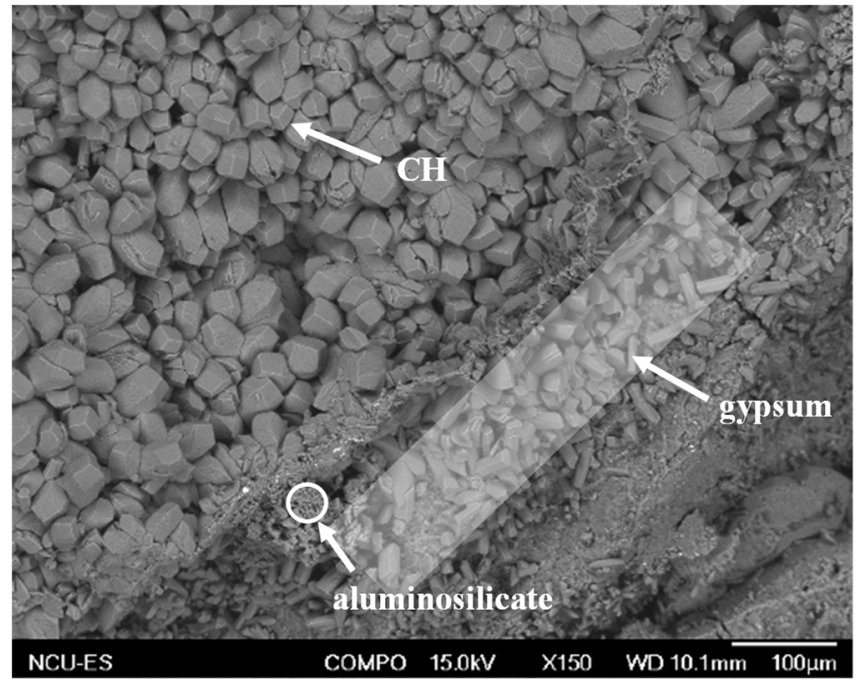

(b)

Figure 7. Cont. 


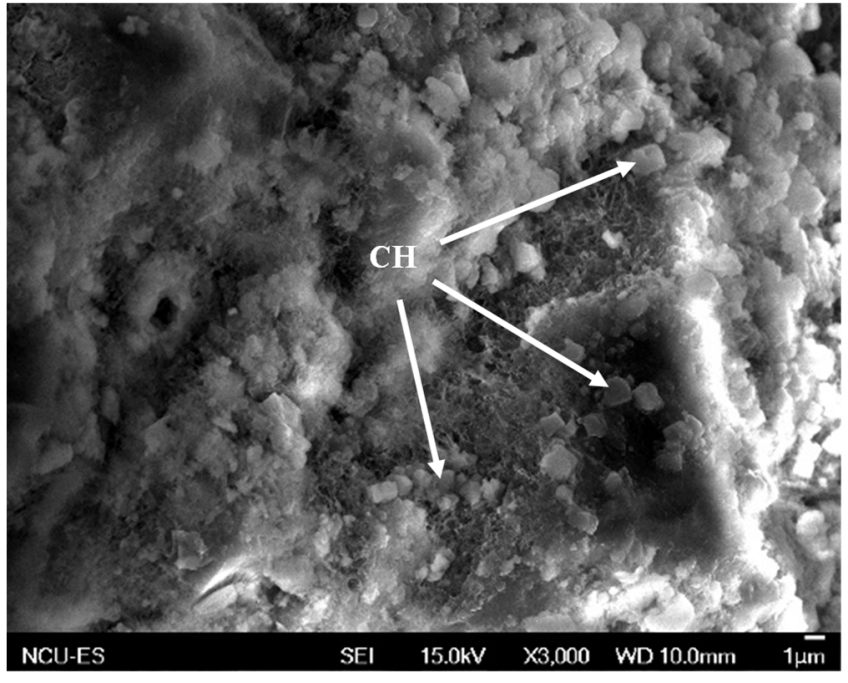

(c)

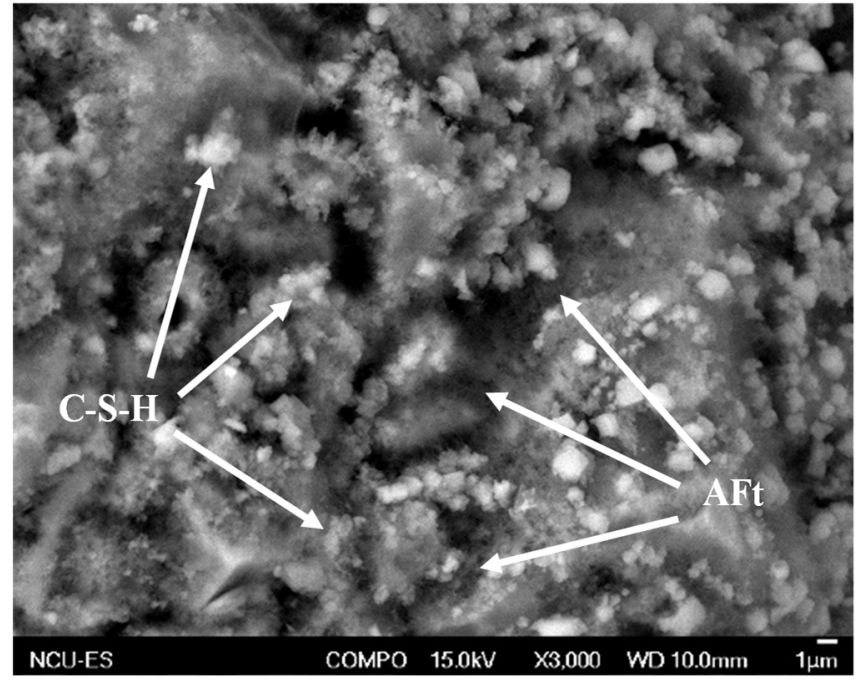

(d)

Figure 7. SEM micrograph of CFB-BFS blended paste under external sulfate attack for 180 days. (a) SEM micrograph of ESA products. (b) ESA products near the outer side. (c) ESA products $\left(\mathrm{Ca}(\mathrm{OH})_{2}\right)$ observed on the inner part. (d) ESA products (Aft and C-S-H) observed on the inner part.

In the SEM observations, it can be seen that the CFB fly ash-BFS blended paste exposed to external sulfate attack does have gypsum crystals formation near the surface of the specimen in contact with the sulfate solution (e.g., Figure 7b), but no significant gypsum crystals and large amounts of secondary ettringite formation was observed in the deeper internal pores (the size of secondary ettringite formation is significantly several times larger than the normal size $(1-2 \mu \mathrm{m})$ of AFt). The formation of gypsum crystals and secondary ettringite formation in the internal pores of the mortar are expected to cause an increase in pore pressure, which in turn leads to structural expansion and damage and is generally considered to be the main cause of volume expansion. On the other hand, the formation of solid solution from sulfoaluminate hydrates in the presence of $\mathrm{SiO}_{2}$ and $\mathrm{Al}_{2} \mathrm{O}_{3}$ that are rich in BFS gives rise to dimensionally stable products.

Therefore, this result of not finding gypsum crystals and secondary ettringite formation inside the pore space of the specimen explains why the CFB fly ash-BFS blended paste exhibits negligible expansion under external sulfate attack.

\subsubsection{Internal Sulfate Attack (ASTM C1038)}

An important form of internal sulfate attack on concrete is delayed or secondary ettringite formation, which generally originates in cementitious material or aggregate with high sulfate contents $\left(\mathrm{SO}_{3}\right)$.

Taylor et al. [17] defined delayed ettringite formation (DEF) as the formation of ettringite in a cementitious material by a process that begins after hardening, which is substantially complete and that involves none of the sulfate from the outer source of cement paste. Rajczyk et al. [18] showed that anhydrite $\left(\mathrm{CaSO}_{4}\right)$ present in hydrating cement-CFB fly ash blended material can be the source of delayed ettringite formation, reducing the durability of hardened concrete.

The high $\mathrm{SO}_{3}$ content in binder or aggregate may produce excessive ettringite (AFt) and leads to expansion and disintegration of mortar specimen. In this study, the CFB fly ash has a $\mathrm{SO}_{3}$ content of over 25\%, exceeding the limit specified in ASTM C618 [19]. ASTM C1038 test was designed to detect such situation. Standard mortar bars were soaked in water for 14 days, and an expansion value less than $0.02 \%$ is considered satisfactory (ASTM C1038).

The aim of this experiment was to evaluate the effects of different CFB fly ash-BFS blending ratio on expansion behavior of mortar specimen due to internal sulfate attack. 
Figure 8 shows the expansion up to 360 days of storage in saturated lime solution. It is observed that martars made with CFB fly ash to SBM ratio less than $20 \%$ exbibited very limited volume expansion upon submersion in saturated lime solution. On the other hand, the volume expansion of mortars with CFB fly ash/SBM ratio greater than $25 \%$ was found to be significantly higher and exceeded the limiting criterium of $0.02 \%$ at 14 days.

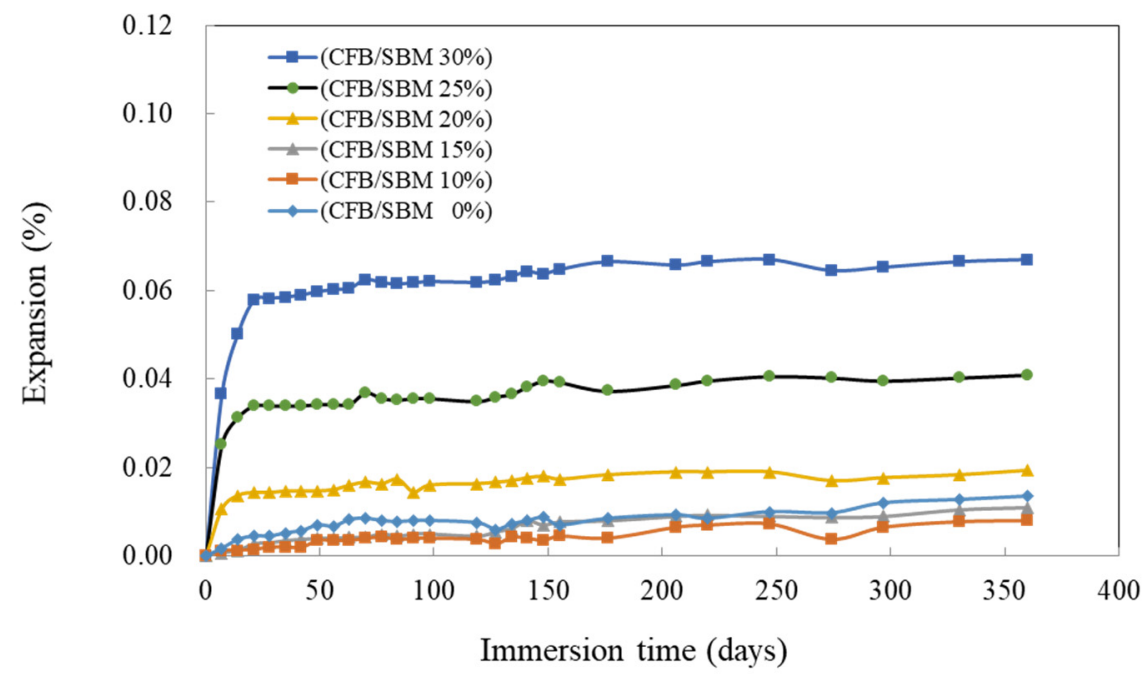

Figure 8. Expansion of mortars with different CFB fly ash/SBM ratio under internal sulfate attack.

It is noted that the expansion of mortar bars with different proportions of CFB fly ash-BFS reached a high value within a few days and followed by an obvious tendency to level off. The expansion rates do not change much after about 30 days of immersion. This indicates that the expansion of CFB-BFS blended mortars occurred in the early ages of the test, and the reaction is rapid. Moreover, the expansion rate is proportional to the amount of CFB fly ash in the blend. This may be due to the fact that the saturated lime solution provides a large amount of free $\mathrm{Ca}^{2+}$ to react with the internal sulfate in the CFB fly ash-BFS blended mortar, resulting in the rapid expansion and instability of the mortar.

Scanning electron microscopy (SEM) was used to study the microstructure of the specimens, consisting of $20 \%$ cement, $64 \%$ BFS, and $16 \%$ CFB fly ash after 180 days of exposure to saturated lime solution. The microstructure and hydration products in the outer and inner parts of the specimen are shown in Figure 9. As can be observed in Figure 9b, large size (5-25 $\mu \mathrm{m}$ in length) and massive quantity of needle-like secondary ettringite formation can be observed both in the outer side (in contact with the solution) and the inner side of the blended paste specimen.

The chemical composition was determined by using the SEM phase observation and energy dispersive $X$-ray spectroscopy (EDS) analysis. As shown in Figure 9c, over $10 \mu \mathrm{m}$ needle-like DEF crystals can be observed in the voids of the inner part of the specimen. The EDS spectrum is depicted in Figure 9d, showing that the needle crystals consist of elements $\mathrm{Al}, \mathrm{Si}, \mathrm{S}$, and $\mathrm{Ca}$, which are indicative of the characteristic of ettringite.

Comparing the microstructure and AFt formation of the CFB fly ash-BFS blended paste observed in Figure 5 to those of the DEF under internal sulfate attack shown in Figure 9, it is noted that they are quite different in terms of ettringite size and morphology. This indicates that the paste blended with excessive $\mathrm{CFB}$ fly ash having high $\mathrm{SO}_{3}$ content releases sulfates to react with the large amount of $\mathrm{Ca}^{2+}$ in the solution and forms secondary ettringite. 


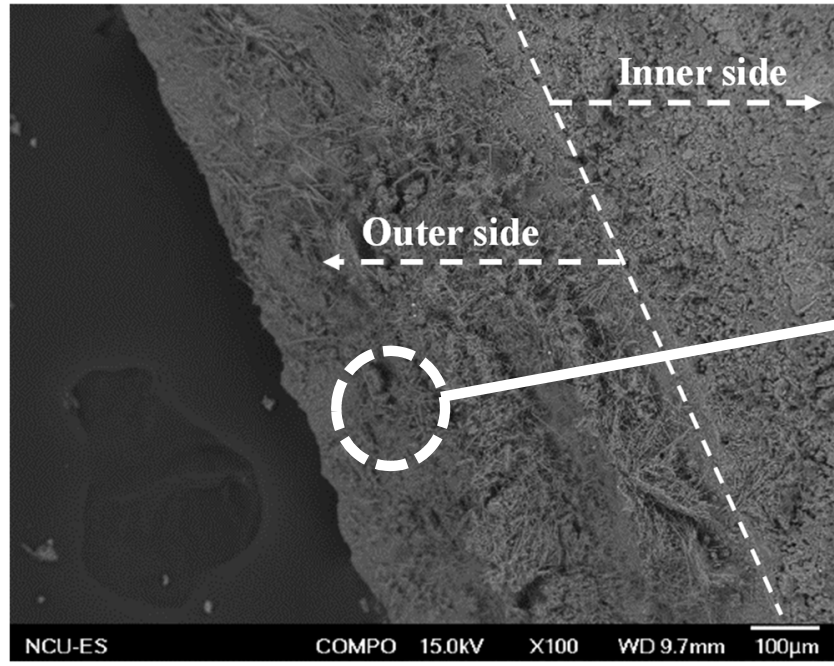

(a)

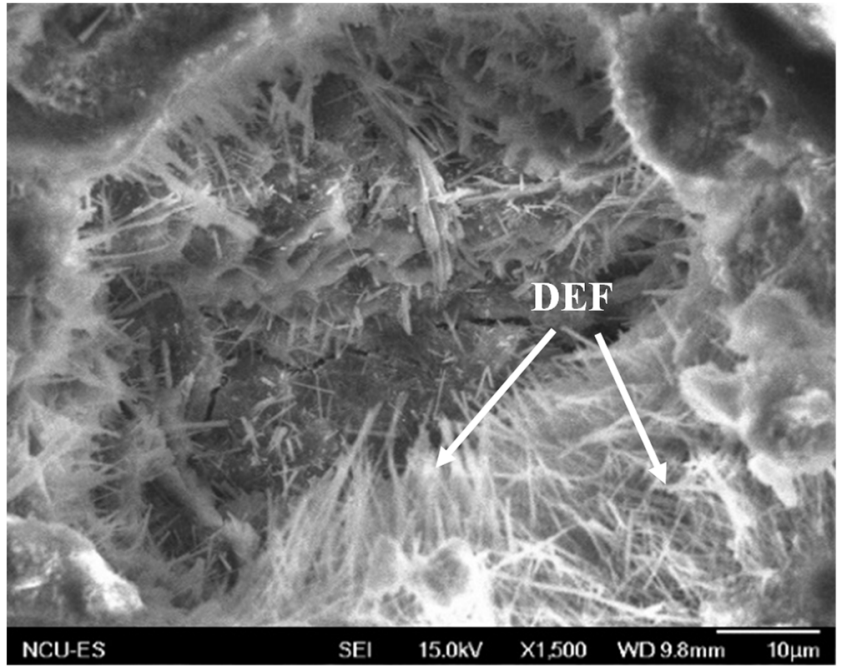

(c)

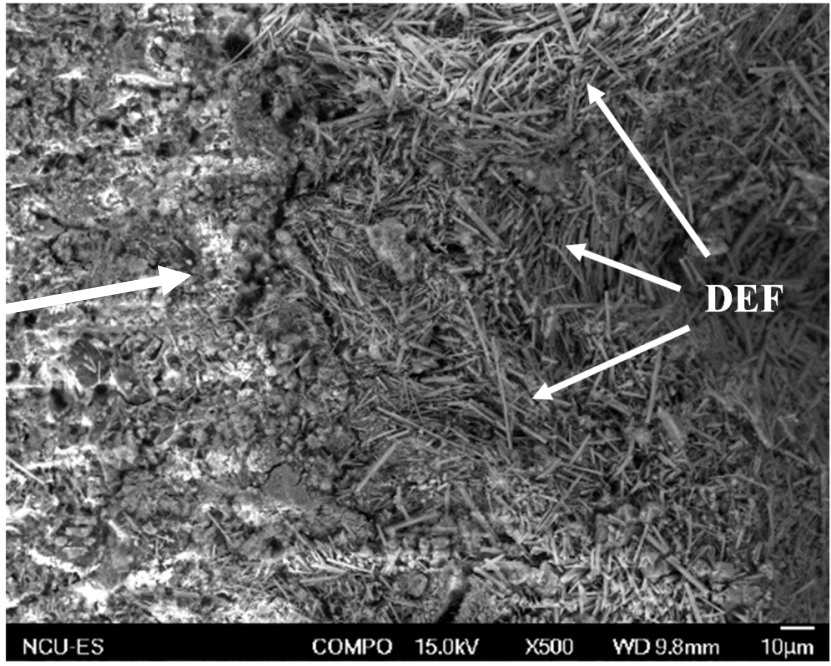

(b)

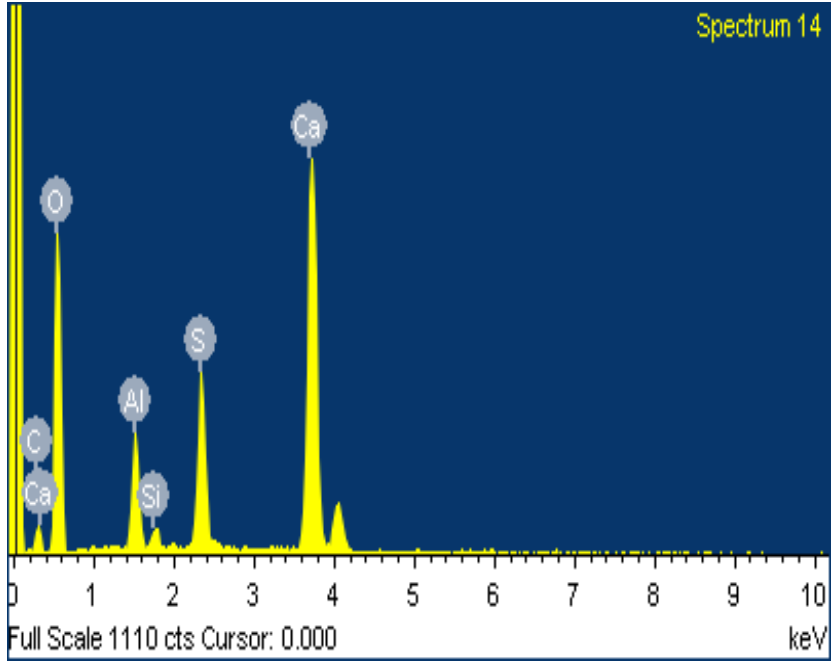

(d)

Figure 9. SEM micrograph of CFB fly ash-BFS blended paste under internal sulfate attack at 180 days. (a) SEM micrograph of ISA products. (b) ISA products (DEF) observed on the outer part. (c) ISA products (DEF) observed on the inner part. (d) EDX spectrum of the DEF.

On the other hand, internal sulfate attack and volume expansion caused by the presence of excessive sulfate is generally avoidable by limiting the CFB fly ash content in the blend. Based on the results of this study, it is recommended that a suitable amount of CFB fly ash be blended with BFS at a ratio of no more than $20 \%$ in order to maintain the dimensional stability of the concrete.

\section{Conclusions}

Experimental study was conducted on mixtures of cement-BFS-CFB fly ash as binder to observe the hydration products, and the volume stability of the mixtures was evaluated for internal and external sulfate attack. The following conclusions were drawn:

1. CFB fly ash sampled from different production batches was found to have stable quality based on the steady compressive strength development exhibited by mortars made with appropriate proportion of CFB fly ash, BFS, and cement.

2. The main hydration products of the CFB fly ash-BFS-cement blends were found to be C-S-H gel, ettringite (AFt), gypsum, and some portlandite $(\mathrm{CH})$. Anhydrite, portlandite, and calcium silicate hydrate can be found within $24 \mathrm{~h}$ of hydration. 
3. The high content of $\mathrm{SO}_{3}$ in $\mathrm{CFB}$ fly ash does not cause noticeable expansion of mortars containing various amounts of CFB fly ash upon external sulfate attack. ASTM C1012 test results show all mortar mixtures containing CFB fly ash have expansion much less than $0.1 \%$ after 270 days of immersion. The binders consisting of Portland cement, BFS, and CFB fly ash have much-improved resistance to external sulfate attack than OPC.

4. Secondary or delayed ettringite formation is likely to occur in mortars containing excessive amount of CFB fly ash. According to the internal sulfate attack (ISA) test result by ASTM C1038, it shows that mixtures containing CFB fly ash release sulfates from high $\mathrm{SO}_{3}$ content in saturated lime solution and react with the large amount of free $\mathrm{Ca}^{2+}$ provided in the solution. Excessive use of CFB fly ash in a binder mixture may lead to the formation of secondary or delayed ettringite and affect the durability of the concrete through rapid expansion behavior. To maintain the dimensional stability of concrete, a suitable amount of CFB fly ash is suggested to be mixed with BFS at a weight ratio of no more than $20 \%$.

Author Contributions: Conceptualization, G.-Y.C. and W.-H.H.; methodology, G.-Y.C. and W.H.H.; investigation, G.-Y.C.; data curation, G.-Y.C.; writing-original draft preparation, G.-Y.C.; writing-review and editing, W.-H.H. All authors have read and agreed to the published version of the manuscript.

Funding: This research received no external funding.

Informed Consent Statement: Not applicable.

Data Availability Statement: The data presented in this study are available within the article.

Conflicts of Interest: The authors declare no conflict of interest.

\section{References}

1. Poon, C.S.; Kou, S.C.; Lam, L.; Lin, Z.S. Activation of fly ash/cement systems using calcium sulfate anhydrite $\left(\mathrm{CaSO}_{4}\right)$. Cem. Concr. Res. 2001, 31, 873-881. [CrossRef]

2. Iribarnea, J.; Iribarnea, A.; Blondinb, J.; Anthonyc, E.J. Hydration of combustion ashes a chemical and physical study. Fuel 2001, 80, 773-784. [CrossRef]

3. Berry, E.E.; Anthony, E.J. Evaluation of potential uses of AFBC solid wastes. MRS Proc. 1987, 86, 353-364. [CrossRef]

4. Shen, Y.; Qian, J.S.; Zhang, Z.W. Investigations of anhydrite in CFBC fly ash as cement retarders. Construct. Build. Mater. 2013, 40, 672-678. [CrossRef]

5. Wu, Y.H.; Anthony, E.J.; Jia, L.F. Experimental studies on hydration of partially sulphated CFBC ash. Can. J. Chem. Eng. 2003, 81, 1200-1214. [CrossRef]

6. Sheng, G.; Zhai, J.; Li, Q.; Li, F. Utilization of fly ash coming from a CFBC boiler co-firing coal and petroleum coke in Portland cement. Fuel 2007, 86, 2625-2631. [CrossRef]

7. Sheng, G.; Li, Q.; Zhai, J. Investigation on the hydration of CFBC fly ash. Fuel 2012, 98, 61-66. [CrossRef]

8. Fu, X.; Li, Q.; Zhai, J.; Sheng, G.; Li, F. The physical-chemical characterization of mechanically-treated CFBC fly ash. Cem. Concr. Compos. 2008, 30, 220-226. [CrossRef]

9. Freidin, C. Hydration and strength development of binder based on high calcium oil shale fly ash. Cem. Concr. Res. 1998, 28, 829-839. [CrossRef]

10. Sung, C.H.; Huang, R.; Wu, Y.H.; Tsaia, C.J.; Lai, H.W. Influence of sulfur trioxide on volume change and compressive strength of eco-mortar. Construct. Build. Mater. 2016, 114, 464-469. [CrossRef]

11. Chen, G.Y.; Huang, W.H. Investigation on blending CFB ash with blast furnace slag as replacement for portland cement used in concrete binders. Adv. Mater. Res. 2013, 723, 623-629. [CrossRef]

12. ASTM C1012Standard Test Method for Length Change of Hydraulic-Cement Mortars Exposed to a Sulfate Solution, ASTM International: West Conshohocken, PA, USA, 2019.

13. ASTM C1038Standard Test Method for Expansion of Portland Cement Mortar Bars Stored in Water, ASTM International: West Conshohocken, PA, USA, 2020.

14. Wilińska, I.; Pacewska, B. Influence of selected activating methods on hydration processes of mixtures containing high and very high amount of fly ash. J. Therm. Anal. Calorim. 2018, 133, 823-843. [CrossRef]

15. Clifton, J.R.; Ponnersheim, J.M. Sulfate Attack of Cementitious Materials: Volumetric Relations and Expansions; NIST and U.S. Department of Commerce: Gaithersburg, MD, USA, 1994.

16. Mehta, P.K. Mechanism of sulfate attack on portland cement concrete-another look. Cem. Concr. Res. 1983, 13, 401-406. [CrossRef]

17. Taylor, H.F.W.; Famy, C.; Scrivener, K.L. Delayed ettringite formation. Cem. Concr. Res. 2001, 31, 683-693. [CrossRef] 
18. Rajczyk, K.; Giergiczny, E.; Glinicki, M.A. Use of DTA in the investigations of fly ashes from fluidized bed boilers. J. Therm. Anal. Calorim. 2004, 77, 165-170. [CrossRef]

19. ASTM C618Standard Specification for Coal Fly Ash and Raw or Calcined Natural Pozzolan for Use in Concrete, ASTM International: West Conshohocken, PA, USA, 2019. 